\title{
Pengaruh Kebiasaan Membaca dan Kecerdasan Interpersonal terhadap Kemampuan Menulis Cerita Pendek
}

\author{
Surtinah \\ Fakultas Pascasarjana, Universitas Indraprasta PGRI \\ Jalan Nangka No. 58 C/TB. Simatupang, Tanjung Barat, \\ Jakarta Selatan 12530 \\ ssurtinah@yahoo.com
}

\begin{abstract}
This research is a kind of survey and aims to find out and analyze empirically the effects of reading habit and interpersonal intelligence towards student's short-story writing ability. The observed population of this research is students from state junior high schools in South Jakarta. The sample was gained through simple random sampling, which means that the researcher mixed the subjects in the population so that they will be considered the same. This research has 3 variables which are divided into 2 independent variables (reading habit and interpersonal intelligence) and 1 dependent variable (student's short-story writing ability). The collection of the data is done by questionnaire and written test for independent and dependent variables. The gained data was then analyzed by using the correlation technique and multiple regressions. Previously, the prerequisite test before examining the regression test must be accomplished. The results of this research are: 1) There are significant effects of reading habit and interpersonal intelligence altogether towards student's short-story writing ability. It is proved by Sig. $=0.000<$ 0.05 and $F$ observed $=44.586$; 2) There is a significant effect of reading habit towards student's short-story writing ability. It is proved by Sig. $=0.000<0.05$ and observed $=4.870 ; 3$ ) There is a significant effect of interpersonal intelligence towards student's short-story writing ability. It is proved Abstrak. by Sig. $=0.013<0.05$ and observed $=2.578$. To improve student's short-story writing ability, teachers should optimize a student's reading habit and interpersonal intelligence.

Keywords: Reading Habit, Interpersonal Intelligence, Short-Story Writing.
\end{abstract}

\begin{abstract}
Abstrak
Penelitian ini merupakan survei dan bertujuan untuk menemukan dan menganalisis secara empiris pengaruh kebiasaan membaca dan kecerdasan interpersonal secara bersama-sama/ parsial terhadap kemampuan menulis cerita pendek. Populasi terjangkau pada penelitian ini adalah siswa kelas VIII pada Sekolah Menengah Pertama Negeri di Jakarta Selatan, sebanyak 60 responden. Sampel penelitian diperoleh melalui metode simple random sampling. Rancangan penelitian yang digunakan melalui teknik korelasi dengan tiga variabel yang terdiri dari dua variabel bebas, yaitu kebiasaan membaca dan kecerdasan interpersonal serta satu variabel terikat, yaitu kemampuan menulis cerita pendek. Pengumpulan data dilakukan dengan teknik kuesioner serta tes tertulis untuk semua variabel. Data yang terkumpul selanjutnya menggunakan teknik korelasi dan regresi linier berganda. Sebelum data dianalisis, terlebih dahulu dilakukan analisis statistik deskriptif dan uji persyaratan data sebelum uji regresi dilakukan. Hasil penelitian menunjukkan bahwa: 1) Terdapat pengaruh yang signifikan antara kebiasaan membaca dan kecerdasan interpersonal secara bersama-sama terhadap kemampuan menulis cerita pendek. Hal tersebut dibuktikan dengan Sig. $=0,000<0,05$ dan Fhitung = 44,586 ; 2) Terdapat pengaruh yang signifikan kebiasaan membaca terhadap kemampuan menulis cerita pendek. Hal tersebut dibuktikan dengan Sig. $=0,000<0,05$ dan thitung = 4,870; 3) Terdapat pengaruh yang signifikan kecerdasan interpersonal terhadap kemampuan menulis cerita pendek. Hal tersebut dibuktikan dengan Sig.= 0,013 $<0,05$ dan thitung = 2,578. Hal ini berarti bahwa untuk meningkatkan kemampuan menulis cerita pendek siswa guru perlu mengoptimalkan kebiasaan membaca dan kecerdasan interpersonal siswa.
\end{abstract}

Kata Kunci : Kebiasaan membaca, kecerdasan interpersonal, cerita pendek 


\section{PENDAHULUAN}

Bahasa adalah sistem lambang yang berwujud bunyi atau bunyi ujar yang merupakan satu alat komunikasi yang memiliki suatu ketertarikan antarpemakai bahasa. Dalam suatu bahasa terdapat perubahan makna, pemahaman konsep, ide dan pikiran yang berbeda. Menurut Kridalaksana dan Djoko Kentjono yang dikutip oleh Chaer (1994:32) menyatakan bahwa "Bahasa adalah sistem lambang bunyi yang arbitrer dan dipergunakan oleh para anggota kelompok sosial untuk bekerja sama, berkomunikasi dan mengidentifikasikan diri."

Bidang pengajaran bahasa, membagi bahasa dalam dua aspek pengajaran, yaitu: pengajaran kemampuan berbahasa dan pengajaran kemampuan bersastra. Kemampuan berbahasa mencakup kemampuan mendengarkan, berbicara, membaca, dan menulis. Sesuai dengan kerangka standar kompetensi mencakup: standar kompetensi, kompetensi dasar, indikator, dan materi pokok. Penekanannya pada kemampuan wacana nonsastra, baik secara produktif, maupun reseptif.

Keterampilan menulis merupakan salah satu keterampilan yang sangat penting dalam kehidupan manusia. Tarigan (2003:3) menyatakan bahwa menulis merupakan keterampilan berbahasa yang dipergunakan untuk berkomunikasi secara tidak langsung, tidak secara tatap muka dengan orang lain. Dalam pelajaran Bahasa Indonesia terdapat empat keterampilan, yaitu mendengarkan, berbicara, membaca, dan menulis.

Secara definitif, menulis cerita pendek ialah menulis tentang sebuah peristiwa atau kejadian pokok dan sebagai dunia alternatif pengarang (Widyamartaya \& Sudiati, 2005:96). Sedangkan Sumardjo (2001:84) menambahkan bahwa menulis cerita pendek adalah seni keterampilan menyajikan cerita.

Kompetensi menulis dalam pengajaran berbahasa dan bersastra merupakan tataran yang tersulit (karena memerlukan keterampilan berpikir logis dan bernalar) dari ketiga kompetensi lainnya, yaitu mendengarkan, membaca, dan berbicara karena sebelum siswa diajarkan kemampuan ini banyak prasyarat yang harus sudah dimiliki oleh siswa. Prasyarat yang dimaksud adalah kemampuan kebahasaan yang harus dimiliki bukan sekedar kemampuan bidang pengetahuan berbahasa dan bersastra, melainkan lebih pada kemampuan yang sifatnya praktis. Oleh karena itu, para guru dituntut untuk mengajarkan kompetensi kebahasaan dan kesastraan dengan penyajian yang padu. Karena sulitnya, seringkali kita jumpai, setelah mempelajari kemampuan menulis siswa tidak menghasilkan sebuah karya. Kemampuan yang dimiliki hanyalah teori-teori membuat sebuah tulisan.

Keberhasilan seorang guru membimbing siswa mampu menulis yang baik dapat dijadikan tolok ukur keberhasilan dalam mengajar kebahasaan dan kesusastraan. Bagi siswa, kemampuan menulis yang baik dapat menjadi tolok ukur keberhasilan belajar, karena dirinya dapat menjadi manusia yang terampil, produktif, sekaligus menjadi pemantik yang lain agar menjadi sosok manusia yang berilmu dan berwawasan luas. 
Kemampuan menulis merupakan kemampuan berbahasa Indonesia yang sangat penting bagi para siswa, baik selama mereka mengikuti pendidikan di berbagai jenjang dan jenis sekolah, maupun dalam kehidupannya di masyarakat. Keberhasilan pembelajar dalam mengikuti kegiatan belajar-mengajar di sekolah banyak ditentukan oleh kemampuannya dalam menulis. Kemampuan menulis merupakan suatu keterampilan berbahasa yang dipergunakan untuk berkomunikasi secara tidak langsung. Menulis merupakan kegiatan yang produktif dan ekspresif. Kemampuan menulis siswa tidak serta-merta datang begitu saja, tetapi perlu dipelajari dan dilatihkan dengan sungguh-sungguh.

Kondisi yang ada di lapangan menunjukkan bahwa pengajaran bahasa Indonesia belumlah tertangani dengan baik, terutama dalam pembelajaran menulis. Guru dan siswa dengan perangkat pembelajarannya yang ada, belum mampu mengoptimalkan proses pembelajaran, sehingga hasil yang diharapkan belum terlihat. Proses belajar-mengajar bahasa Indonesia belum maksimal. Hal ini ditandai dengan guru belum dapat membina dan mengembangkan kemampuan menulis siswa.

Ketidakmampuan siswa Sekolah Menengah Pertama (SMP) dalam hal menulis merupakan fakta yang ada. Hal ini terlihat dalam tulisan-tulisan mereka, baik dalam bentuk tulisan ilmiah, maupun tulisan nonilmiah, misalnya surat pribadi, catatan buku harian, ringkasan jawaban pertanyaan esai berstruktur, menulis paragraf, dan terlebih lagi dalam menulis naskah drama dengan topik yang ditentukan. Pada kenyataannya hasil tulisan para siswa terlihat belum sempurna. Hal ini sangat terasa pada saat guru bahasa dan sastra Indonesia menilai tulisan mereka, baik dari segi ide yang tertuang, maupun segi tulisannya.

Fenomena mengenai kemampuan menulis siswa yang belum menunjukkan hasil yang baik juga terjadi di jenjang sekolah menengah pertama (dalam penelitian kali ini di Sekolah Menengah Pertama Negeri di Jakarta Selatan). Kenyataan di lapangan menunjukkan bahwa kegiatan belajar-mengajar bahasa Indonesia belum menjadi kegiatan belajar-mengajar yang sangat digemari siswa. Hal ini terlihat dari hasil belajar siswa tiga tahun terakhir. Pada tahun pelajaran 2015/2016 kemampuan siswa dalam menulis cenderung masih rendah. Hal ini terlihat dari hasil tulisan siswa dalam menulis surat, buku harian, memo, atau drama. Kondisi serupa terjadi pada tahun pelajaran 2016/2017. Hal ini terlihat dari hasil pekerjaan siswa yang diperiksa Guru Mata Pelajaran Bahasa Indonesia. Ada perubahan menuju perbaikan, tetapi belum menunjukkan hasil yang maksimal. Hal seperti itu terjadi pula pada tahun pelajaran 2017/2018. Kenyataannya terlihat dari karya siswa yang berupa tulisan baik surat, buku harian, memo, bahkan karya sastra berupa drama masih belum menunjukkan hasil optimal.

Rendahnya kemampuan menulis siswa antara lain disebabkan oleh belum terlaksananya hakikat pembelajaran menulis. Proses pembelajaran menulis pada semua jenjang pendidikan ternyata lebih banyak berpusat pada segala sesuatu tentang menulis. Siswa lebih banyak mendapat teori-teori tentang format, tata cara dan kaidah-kaidah penulisan. Kalaupun ada latihan-latihan penerapan kemampuan menulis tersebut dilaksanakan ternyata yang dilatihkan hanyalah sebatas 
bimbingan siswa agar terampil menulis dengan format, tata cara dan kaidahkaidah yang dimaksud, kemudian dikaitkan dengan pola berbahasa yang baik dan benar. Dalam kenyataan kemampuan menulis cerita siswa yang rendah mungkin disebabkan oleh berbagai faktor, misalnya: kebiasaan membaca siswa yang masih rendah dan juga kecerdasan bersosialisasi/ interpersonal yang masih kurang.

Menurut Tarigan (2003:11-12) kebiasan membaca merupakan proses konstruktif, sehingga seorang yang memiliki kebiasaan membaca memiliki beberapa kriteria, yaitu membaca dengan lancar, membaca dilakukan dengan strategi yang tepat, membaca memerlukan motivasi, serta membaca merupakan keterampilan yang harus dikembangkan secara berkesinambungan. Berdasarkan pengamatan awal, siswa Sekolah Menengah Pertama Negeri (SMP) Negeri di Jakarta Selatan kurang termotivasi untuk membaca. Ini disebabkan karena berbagai hal, di antaranya kemajuan teknologi yang menyebabkan kegiatan membaca (yang menyita banyak waktu), digantikan dengan kegiatan visual yang sifatnya instan seperti menonton film dan menggunakan perangkat multimedia lainnya (misalnya: komputer dan telpon genggam). Padahal, dengan memiliki kebiasaan membaca yang baik, siswa akan memperoleh pengetahuan yang cukup yang diperlukan untuk menulis dan menuangkan ide lainnya.

Hal lain yang menghambat kemampuan siswa dalam menulis cerita pendek adalah kecerdasan interpersonal. Kecerdasan interpersonal adalah kemampuan untuk berhubungan dengan orang-orang di sekitar kita, kecerdasan ini adalah kemampuan kita untuk memahami dan memperkirakan perasaan, temperamen, suasana hati, maksud dan keinginan orang lain dan menanggapinya secara layak (Lwin dkk, 2008:197). Siswa Sekolah Menengah Pertama Negeri (SMP) Negeri di Jakarta Selatan memiliki kemampuan interpersonal yang kurang karena mereka kerap menggunakan perangkat elektronik (telpon genggam), sehingga mereka asyik dengan dunianya sendiri, tanpa mau peduli dengan dunia sekitarnya. Fenomena menarik dapat ditemui, manakala mereka bertemu dengan teman di pusat perbelanjaan (shopping center), walaupun mereka kerap bersama teman sebaya, namun mereka tetap asyik dengan gadget yang mereka punya dan berbicara dengan teman seadanya. Perilaku ini menyebabkan siswa kurang memiliki dan mengembangkan kecerdasan interpersonal. Padahal, kecerdasan interpersonal diperlukan siswa dalam proses belajar dan mengembangkan ide, sehingga kebuntuan dalam berkomunikasi baik secara langsung maupun tidak langsung dapat diminimalkan. Komunikasi yang baik (terutama secara tidak langsung), akan dapat meningkatkan taraf intelektual dan prestasi yang optimal, termasuk dalam kemampuan menulis cerita pendek. Jadi, permasalahan utama para siswa adalah kurangnya kemampuan menulis cerita pendek. Sebagian besar siswa mengalami kesulitan dalam hal menulis. Kesulitan siswa dalam menulis sebagian besar ditunjukkan dalam karangan esai mereka, termasuk dalam menulis cerita pendek. Oleh karena itu, masalah kemampuan menulis cerita pendek siswa cukup menarik untuk diteliti lebih lanjut dalam kaitannya dengan kebiasaan membaca dan kecerdasan interpersonal siswa di Sekolah Menengah Pertama Negeri (SMPN) di Jakarta Selatan. 
Dari beberapa uraian di atas, penulis berpendapat bahwa faktor kebiasaan membaca dan kecerdasan interpersonal ada hubungannya dengan kemampuan siswa dalam menulis, termasuk pula dalam menulis cerita pendek. Oleh karena itu, penulis tertarik untuk meneliti lebih lanjut tentang pengaruh kebiasaan membaca dan kecerdasan interpersonal terhadap kemampuan menulis cerita pendek siswa Sekolah Menengah Pertama Negeri (SMPN) di Jakarta Selatan.

\section{METODE}

Metode yang digunakan dalam penelitian ini adalah metode survei dengan teknik korelasional. Variabel penelitian ini terdiri dari variabel terikat, yaitu kemampuan menulis cerita pendek siswa (Y) dan dua variabel bebas, yaitu: kebiasaan membaca $\left(\mathrm{X}_{1}\right)$ dan kecerdasan interpersonal $\left(\mathrm{X}_{2}\right)$. Konstelasi hubungan antar variabel dalam penelitian ini dapat digambarkan sebagai berikut:

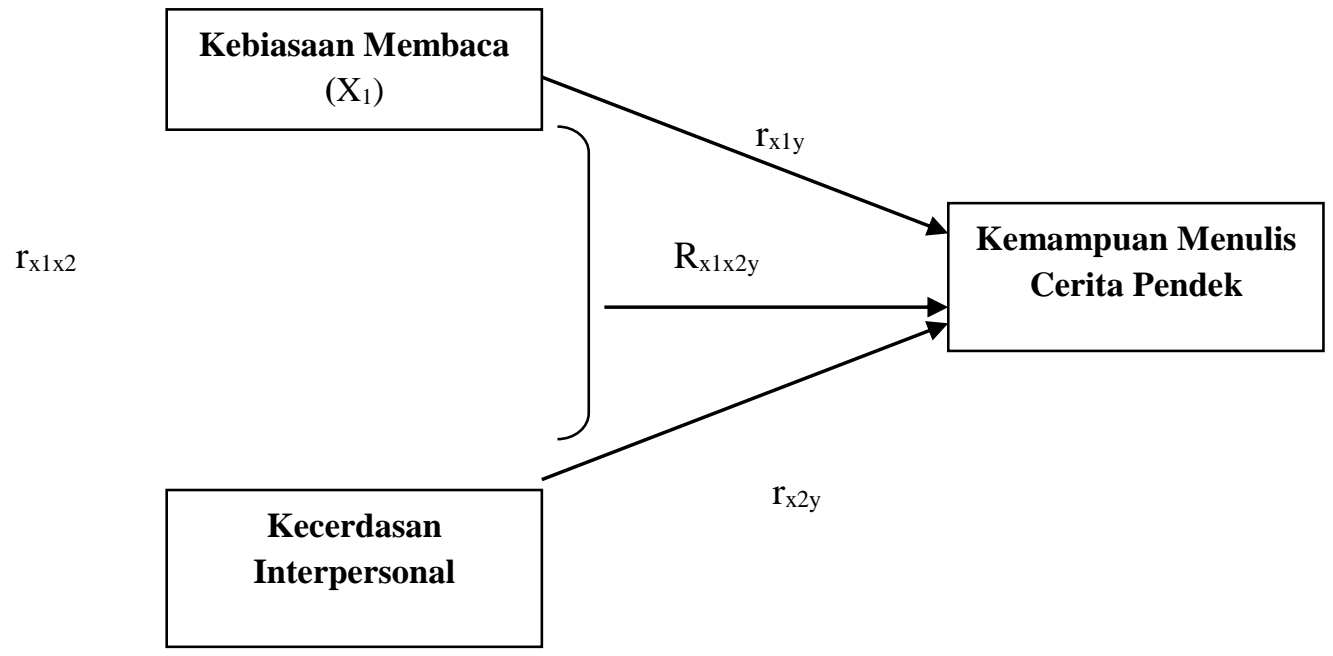

\section{Gambar 1 \\ Paradigma Penelitian}

Keterangan:
Variabel Bebas $\left(\mathrm{X}_{1}\right) \quad$ : kebiasaan membaca
Variabel Bebas $\left(\mathrm{X}_{2}\right) \quad$ : kecerdasan interpersonal
Variabel Terikat $(\mathrm{Y}) \quad$ : kemampuan menulis cerita pendek

Pengumpulan data penelitian dilakukan dengan berpedoman pada variabel penelitian, dalam hal ini dibedakan menjadi tiga variabel penelitian, yaitu: 1 . Variabel Kebiasaan Membaca; Teknik pengumpulan data kebiasaan membaca ini dilakukan dengan instrumen nontes berbentuk angket. Sumber data dalam penelitian adalah siswa yang terpilih sebagai sampel penelitian. 2. Varibel Kecerdasan Interpersonal; Teknik pengumpulan data kecerdasan interpersonal ini dilakukan dengan instrumen nontes berbentuk angket. Sumber data dalam penelitian ini adalah siswa yang terpilih sebagai sampel penelitian. 3. Variabel 
Kemampuan Menulis Cerita Pendek; Teknik pengumpulan data untuk variabel kemampuan menulis cerita pendek siswa adalah dengan melakukan ulangan atau tes terhadap sampel dengan menggunakan instrumen berupa tes uraian.

Sampel dalam penelitian ini adalah 60 orang. Untuk menentukan anggota sampel dari setiap sekolah dipilih secara acak. Menurut Roscoe dalam Sugiyono (2013:74) mengatakan bahwa bila dalam penelitian akan melakukan analisis multivariate (korelasi atau regresi ganda), maka jumlah sampel minimal 10 kali jumlah variabel yang akan diteliti (minimal 30 orang sampel). Berdasarkan pendapat tersebut, maka jumlah sampel pada penelitian ini ditetapkan sebanyak 60 orang siswa. Proses pengambilan sampel adalah sebagai berikut: pada masingmasing sekolah diambil 2 kelas dan pada masing-masing kelas diambil 10 orang secara acak. Jadi, tiap sekolah sampel yang diambil adalah 20 orang, sehingga jumlah seluruh sampel pada 3 sekolah tersebut adalah 60 orang, yaitu siswa kelas VIII SMPN 37, SMPN 68, dan SMPN 226 masing-masing 20 siswa.

Sumber-sumber data dalam penelitian ini adalah siswa yang dijadikan sampel pada 3 SMP Negeri di Kecamatan Cilandak, Jakarta Selatan. Sesuai dengan variabel penelitian, ada tiga jenis data yang dikumpulkan, yaitu tentang: 1) kebiasaan membaca, 2) kecerdasan interpersonal, dan 3) kemampuan menulis cerita pendek. Untuk memperoleh data tentang kebiasaan membaca dan kecerdasan interpersonal, dalam penelitian ini digunakan angket/ kuesioner, sedangkan data tentang kemampuan menulis cerita pendek diambil dari tes tertulis (esai) berupa menulis karangan tentang cerita pendek sesuai dengan soal yang sudah dirancang.

Instrumen yang digunakan dalam penelitian ini adalah: (1) tes kemampuan menulis cerita pendek berbentuk soal esai (uraian) berdasarkan topik yang telah disediakan dengan butir penilaian yang sudah dirancang, (2) angket kebiasaan membaca dan (3) angket kecerdasan interpersonal. Untuk variabel bebas kebiasaan membaca dan kecerdasan interpersonal menggunakan sistem penilaian (scoring) nondikotomis, berupa angket, sedangkan untuk variabel terikat (kemampuan menulis cerita pendek), menggunakan rentang skor 1-10 untuk tiap butir penilaian instrumennya.

Secara operasional, kebiasaan membaca adalah skor total jawaban siswa terhadap kuesioner mengenai kebiasaan membaca yang disusun beberapa indikator: 1) kesenangan membaca; 2) kemampuan berpikir kritis lewat proses membaca; 3) motivasi dan minat membaca; 4)ide/gagasan yang didapat lewat membaca; dan 5) pemahaman makna. Penskoran yang diberikan menggunakan data nonparametrik, dengan penskoran menggunakan skala Likert (Likert scale), dengan kriteria: 5 untuk Sangat Setuju (SS) hingga 1 untuk Sangat Tidak Setuju (STS).

Kecerdasan interpersonal adalah skor total jawaban siswa terhadap angket mengenai kecerdasan interpersonal yang disusun berdasarkan dimensi: 1) social sensitivity; 2) social insight dan; 3) social communication. Dari ketiga dimensi tersebut, kemudian diturunkan menjadi beberapa indikator. Penskoran akan diberikan menggunakan data nonparametrik, dengan penskoran menggunakan 
skala Likert (Likert scale), dengan kriteria: 5 untuk Sangat Setuju (SS) hingga 1 untuk Sangat Tidak Setuju (STS)

Kemampuan menulis cerita pendek adalah skor total jawaban siswa terhadap tes menulis cerita pendek yang disusun berdasarkan indikator: tema, setting, penokohan, ilustrasi tokoh, sudut pandang, penciptaan alur, penciptaan amanat, ketepatan ejaan, diksi, dan ketepatan teknik penulisan.

Dalam analisis deskriptif akan dilakukan teknik penyajian data dalam bentuk tabel distribusi frekuensi, grafik poligon dan histogram untuk masingmasing variabel penelitian. Selain itu, juga masing-masing kelompok data akan diolah dan dianalisis ukuran pemusatan dan letak mean, median, dan modus serta ukuran simpangan seperti jangkauan, variansi, simpangan baku, kemencengan dan kurtosis. Untuk perhitungan analisis deskriptif digunakan program SPSS version 22.0 for Windows.

Setelah keseluruhan uji persyaratan analisis data dipenuhi dan diketahui data layak untuk diolah lebih lanjut, maka langkah berikutnya adalah menguji masingmasing hipotesis yang telah diajukan. Pengujian hipotesis yang dilakukan adalah dengan menggunakan teknik korelasi regresi linier berganda. Hal ini digunakan untuk mencari pengaruh antarvariabel, yaitu: pengaruh kebiasaan membaca dan kecerdasan interpersonal secara bersama-sama terhadap kemampuan menulis cerita pendek, pengaruh kebiasaan membaca terhadap kemampuan menulis cerita pendek, dan pengaruh kecerdasan interpersonal terhadap kemampuan menulis cerita pendek. Pengujian dalam perhitungan uji hipotesis juga digunakan bantuan program SPSS version 22.0 for Windows.

\section{HASIL DAN PEMBAHASAN}

Data dari kebiasaan membaca diperoleh berdasarkan hasil angket/ kuesioner. Angket terdiri dari 20 butir pernyataan dengan 60 orang responden. Tiap item diberi skor dari 1 sampai 5 menurut skala Likert (preferential scale).

Tabel 1. Deskripsi Data Penelitian 
Diskursus: Jurnal Pendidikan Bahasa Indonesia

Vol. 1, No. 1, April 2018, pp. 97-108

p-ISSN: $2615-4935$

e-ISSN: 2615-4943

\begin{tabular}{|l|r|r|r|}
\hline \multicolumn{3}{|c|}{ Statistics } \\
\hline Valid $\quad$ Missing & $\begin{array}{c}\text { Kebiasaan } \\
\text { Membaca }\end{array}$ & $\begin{array}{c}\text { Kecerdasan } \\
\text { Interpersonal }\end{array}$ & $\begin{array}{c}\text { Kemampuan } \\
\text { Menulis } \\
\text { Cerita Pendek }\end{array}$ \\
\hline Mean & 60 & 60 & 60 \\
Median & 0 & 0 & 0 \\
Mode & 76.08 & 87.38 & 54.13 \\
Std. Deviation & 76.00 & 88.00 & 54.00 \\
Skewness & 81 & 93 & 50 \\
Std. Error of Skewness & 4.982 & 7.078 & 4.515 \\
Kurtosis & -.124 & -.169 & .477 \\
Std. Error of Kurtosis & .309 & .309 & .309 \\
Minimum & -1.282 & -1.176 & -.533 \\
Maximum & .608 & .608 & .608 \\
\hline
\end{tabular}

a. Multiple modes exist. The smallest value is shown

Berdasarkan di atas didapatkan bahwa skor maksimum 84 sementara skor minimum 67. Tingkat kebiasaan membaca berada pada angka rata-rata 76,08 , deviasi standar 4,98, median 76 dan modus 81. Angka deviasi standar 4,98 berarti $6,5 \%$ dari skor rata-rata. Ini menunjukan bahwa disparitas kebiasaan membaca relatif cukup rendah. Maka dapat disimpulkan bahwa tingkat kebiasaan membaca bersifat homogen.

Tabel 2 Rekapitulasi Hasil Pengujian Normalitas

\begin{tabular}{|c|c|c|c|c|}
\hline & & $\begin{array}{l}\text { Kebiasaan } \\
\text { Membaca }\end{array}$ & $\begin{array}{c}\text { Kecerdasan } \\
\text { Interpersonal }\end{array}$ & $\begin{array}{l}\text { Kemampuan } \\
\text { Menulis } \\
\text { Cerita Pendek }\end{array}$ \\
\hline$N$ & & 60 & 60 & 60 \\
\hline \multirow[t]{2}{*}{ Normal Parameters ${ }^{2}$} & Mean & 76.08 & 87.38 & 54.13 \\
\hline & Std. Deviation & 4.982 & 7.078 & 4.515 \\
\hline \multirow[t]{3}{*}{ Most Extreme Differences } & Absolute & .138 & .120 & .124 \\
\hline & Positive & .115 & .085 & .124 \\
\hline & Negative & -.138 & -.120 & -.076 \\
\hline Kolmogorov-Smirnov $Z$ & & 1.070 & .926 & .960 \\
\hline Asymp. Sig. (2-tailed) & & .202 & .357 & .316 \\
\hline
\end{tabular}

a. Test distribution is Normal.

Pada tabel di atas, terlihat bahwa nilai pada kolom Sig dengan menggunakan metode Kolmogorov-Smirnov berturut-turut 0,202; 0,357 dan 0,316 yang berarti semua nilai $p$ value-nya ( $\mathrm{Sig}$ ) lebih besar dari 0,05 , sehingga $\mathrm{H}_{0}$ diterima dan $\mathrm{H}_{1}$ otomatis ditolak. Dengan kata lain, dapat disimpulkan bahwa data dari semua 
Diskursus: Jurnal Pendidikan Bahasa Indonesia

Vol. 1, No. 1, April 2018, pp. 97-108

p-ISSN: 2615-4935

e-ISSN: 2615-4943

sampel pada penelitian ini berdistribusi normal. Hasil perhitungan pengujian linieritas garis regresi hubungan antara variabel bebas kebiasaan membaca dan variabel terikat kemampuan menulis cerita pendek siswa dapat dilihat pada tabel di bawah ini:

Tabel 3. Hasil Pengujian Linieritas Garis Regresi Pengaruh Kebiasaan Membaca $\left(\mathrm{X}_{1}\right)$ terhadap Kemampuan Menulis Cerita Pendek (Y)

\begin{tabular}{|c|c|c|c|c|c|c|c|}
\hline \multicolumn{8}{|c|}{ ANOVA Table } \\
\hline & & & $\begin{array}{c}\text { Sum of } \\
\text { Squares }\end{array}$ & $\mathrm{df}$ & Mean Square & $F$ & Sig. \\
\hline \multirow{3}{*}{$\begin{array}{l}\text { Kemampuan Menulis } \\
\text { Cerita Pendek* } \\
\text { Kebiasaan Membaca }\end{array}$} & \multirow[t]{2}{*}{ Between Groups } & (Combined) & 814.960 & 17 & 47.939 & 5.190 & .000 \\
\hline & & Deviation from Linearity & 135.808 & 16 & 8.488 & .919 & .555 \\
\hline & \multicolumn{2}{|l|}{ Within Groups } & 387.974 & 42 & 9.237 & & \\
\hline
\end{tabular}

Pada tabel di atas, terlihat bahwa nilai pada kolom Sig baris Deviation from Linearity adalah 0,555 lebih besar daripada 0,05 , sehingga $\mathrm{H}_{0}$ diterima dan $\mathrm{H}_{1}$ ditolak. Dengan kata lain, dapat dikatakan bahwa garis regresi pengaruh variabel kebiasaan membaca $\left(\mathrm{X}_{1}\right)$ terhadap variabel kemampuan menulis cerita pendek $(\mathrm{Y})$ tersebut bersifat linier. Hasil perhitungan pengujian linieritas garis regresi hubungan antara variabel bebas kecerdasan interpersonal $\left(\mathrm{X}_{2}\right)$ dan variabel terikat kemampuan menulis cerita pendek siswa (Y) dapat dilihat pada tabel berikut ini:

Tabel 4. Hasil Pengujian Linieritas Garis Regresi Pengaruh Kecerdasan Interpersonal $\left(\mathbf{X}_{2}\right)$ terhadap Kemampuan Menulis Cerita Pendek (Y)

\begin{tabular}{|c|c|c|c|c|c|c|c|}
\hline \multicolumn{8}{|c|}{ ANOVA Table } \\
\hline & & & $\begin{array}{c}\text { Sum of } \\
\text { Squares }\end{array}$ & $\mathrm{df}$ & Mean Square & $F$ & Sig. \\
\hline \multirow{5}{*}{$\begin{array}{l}\text { Kemampuan Menulis } \\
\text { Cerita Pendek* } \\
\text { Kecerdasan } \\
\text { Interpersonal }\end{array}$} & Between Groups & (Combined) & 791.017 & 24 & 32.959 & 2.800 & .003 \\
\hline & & Linearity & 538.693 & 1 & 538.693 & 45.772 & .000 \\
\hline & & Deviation from Linearity & 252.324 & 23 & 10.971 & .932 & .562 \\
\hline & Within Groups & & 411.917 & 35 & 11.769 & & \\
\hline & Total & & 1202.933 & 59 & & & \\
\hline
\end{tabular}

Pada tabel di atas, terlihat bahwa nilai pada kolom Sig baris Deviation from Linearity adalah 0,562 lebih besar dari 0,05, sehingga $\mathrm{H}_{0}$ diterima dan $\mathrm{H}_{1}$ otomatis ditolak. Dengan kata lain dapat dikatakan bahwa garis regresi pengaruh variabel kecerdasan interpersonal $\left(\mathrm{X}_{2}\right)$ terhadap variabel kemampuan menulis cerita pendek siswa (Y) tersebut bersifat linier. Dalam penelitian ini perhitungan hipotesis dilakukan seperti ketentuan yang ada. Hasil perhitungan dan pengujian dapat dilihat secara berurutan pada tabel yang disajikan berikut ini:

Tabel 5. Hasil Perhitungan Koefisien Korelasi Pengaruh Variabel Kebiasaan Membaca $\left(X_{1}\right)$ dan Kecerdasan Interpersonal $\left(X_{2}\right)$ terhadap Variabel Kemampuan Menulis Cerita Pendek (Y)

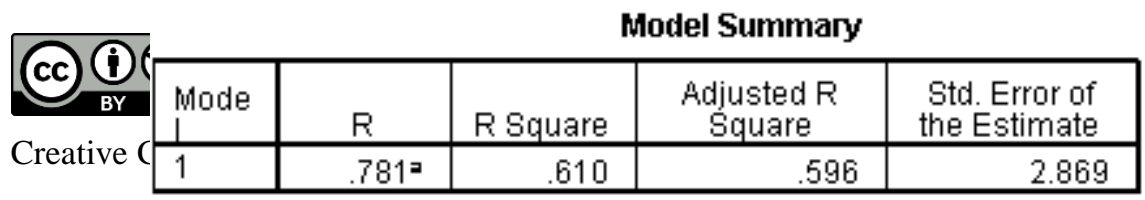


Tabel 6. Rekapitulasi Hasil Perhitungan Pengujian Signifikansi Koefisien

Regresi Pengaruh Variabel Kebiasaan Membaca $\left(X_{1}\right)$ dan Kecerdasan Interpersonal $\left(\mathrm{X}_{2}\right)$ terhadap Variabel Kemampuan Menulis Cerita Pendek

(Y)

ANONA ${ }^{b}$

\begin{tabular}{|ll|r|r|r|r|r|}
\hline \multicolumn{1}{|c|}{} & \multicolumn{1}{c|}{$\begin{array}{c}\text { Sum of } \\
\text { Squares }\end{array}$} & df & Mean Square & F & Sig. \\
\hline 1 & Regression & 733.847 & 2 & 366.924 & 44.586 & $.000=$ \\
& Residual & 469.086 & 57 & 8.230 & & \\
& Total & 1202.933 & 59 & & & \\
\hline
\end{tabular}

a. Predictors: (Constant), Kecerdasan Interpersonal, Kebiasaan Membaca

b. Dependent Variable: Kemampuan Menulis Cerita Pendek

Tabel 7. Rekapitulasi Hasil Perhitungan Persamaan Garis Regresi Pengaruh Variabel Kebiasaan Membaca $\left(X_{1}\right)$ dan Kecerdasan Interpersonal $\left(X_{2}\right)$ terhadap Variabel Kemampuan Menulis Cerita Pendek (Y)

Coefficients $^{\text {s }}$

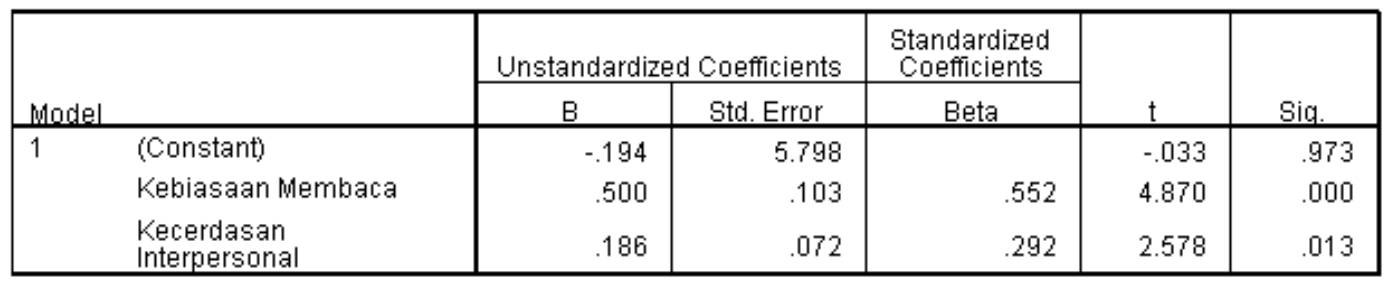

a. Dependent Variable: Kemampuan Menulis Cerita Pendek

Berdasarkan tabel di atas, terlihat bahwa koefisien korelasi ganda pengaruh variabel bebas kebiasaan membaca $\left(\mathrm{X}_{1}\right)$ dan kecerdasan interpersonal $\left(\mathrm{X}_{2}\right)$ secara bersama-sama terhadap kemampuan menulis cerita pendek siswa (Y) adalah sebesar 0,781, sedangkan koefisien determinasinya ( $\mathrm{R}$ square) sebesar 0,610 menunjukkan bahwa besarnya kontribusi kebiasaan membaca dan kecerdasan interpersonal secara bersama-sama terhadap kemampuan menulis cerita pendek siswa adalah sebesar 61\%, sisanya (sebesar 39\%) karena disebabkan faktor lainnya.

Untuk pengujian hipotesis melalui analisis regresi diperoleh hasil perhitungan seperti yang terlihat pada di atas. Berdasarkan tabel tersebut, diperoleh persamaan garis regresi yang mempresentasikan pengaruh variabel kebiasaan membaca $\left(\mathrm{X}_{1}\right)$ dan kecerdasan interpersonal $\left(\mathrm{X}_{2}\right)$ terhadap variabel kemampuan menulis cerita pendek siswa $(Y)$, yaitu: $\hat{Y}=\mathbf{- 0 , 1 9 4}+\mathbf{0 , 5 0 0 X _ { 1 }}+\mathbf{0 , 1 8 6 X _ { 2 }}$. 
Sementara untuk menguji signifikansi garis regresi tersebut adalah dengan memperhatikan hasil perhitungan yang ada pada Tabel 4.6. Menurut ketentuan yang ada, kriteria signifikansi regresi tersebut adalah "jika nilai Sig $<0,05$ maka $\mathrm{H}_{0}$ ditolak dan $\mathrm{H}_{1}$ diterima" atau "jika $\mathrm{F}_{\text {hitung }}>\mathrm{F}_{\text {tabel }}$ maka $\mathrm{H}_{0}$ juga ditolak/ $\mathrm{H}_{1}$ diterima", yang berarti bahwa koefisien regresi tersebut signifikan. Dengan kata lain, kita dapat simpulkan bahwa terdapat pengaruh yang signifikan variabel bebas kebiasaan membaca $\left(\mathrm{X}_{1}\right)$ dan kecerdasan interpersonal $\left(\mathrm{X}_{2}\right)$ terhadap variabel terikat kemampuan menulis cerita pendek (Y). Nilai signifikansi (Sig) adalah bilangan yang tertera pada kolom Sig dalam Tabel 4.6. Nilai Fhitung adalah bilangan yang tertera pada kolom $\mathrm{F}$ dalam tabel yang sama. Nilai $\mathrm{F}_{\text {tabel }}$ adalah nilai tabel distribusi $F$ untuk taraf nyata $5 \%$ dengan derajat pembilang $(\mathrm{k})=2$ dan derajat penyebut $(n-k-1)=57$, dimana $n$ adalah jumlah banyaknya responden dan $\mathrm{k}$ adalah jumlah banyaknya variabel bebas.

Dari tabel tersebut, terlihat bahwa nilai $\mathrm{Sig}=0,000<0,05$ dan $\mathrm{F}_{\text {hitung }}=$ 44,586, maka $\mathrm{H}_{0}$ ditolak dan $\mathrm{H}_{1}$ otomatis diterima yang berarti bahwa koefisien regresi tersebut signifikan. Jadi, dapat dikatakan bahwa terdapat pengaruh yang signifikan antara variabel bebas kebiasaan membaca $\left(\mathrm{X}_{1}\right)$ dan kecerdasan interpersonal $\left(\mathrm{X}_{2}\right)$ secara bersama-sama terhadap kemampuan menulis cerita pendek (Y).

Berdasarkan hasil pengujian korelasi maupun regresi tersebut maka disimpulkan bahwa terdapat pengaruh variabel bebas kebiasaan membaca $\left(\mathrm{X}_{1}\right)$ dan kecerdasan interpersonal $\left(\mathrm{X}_{2}\right)$ secara bersama-sama terhadap kemampuan menulis cerita pendek siswa (Y). Dari tabel tersebut, terlihat bahwa nilai Sig adalah $0,000<0,05$ dan thitung $=4,870$, maka $\mathrm{H}_{0}$ ditolak dan $\mathrm{H}_{1}$ otomatis diterima, yang berarti terdapat pengaruh yang signifikan variabel bebas $\mathrm{X}_{1}$ (kebiasaan membaca) terhadap variabel terikat Y (kemampuan menulis cerita pendek).

\section{SIMPULAN}

Berdasarkan pembahasan yang telah dilakukan, dapat disimpulkan:

1. Terdapat pengaruh yang signifikan kebiasaan membaca dan kecerdasan interpersonal secara bersama-sama terhadap kemampuan menulis cerita pendek siswa SMP Negeri di Jakarta Selatan. Hal tersebut dibuktikan dengan nilai Sig. $0,000<0,05$ dan Fhitung $=44,586$.

2. Terdapat pengaruh yang signifikan kebiasaan membaca terhadap kemampuan menulis cerita pendek siswa SMP Negeri di Jakarta Selatan. Hal tersebut dibuktikan dengan nilai Sig. $0,000<0,05$ dan thitung $=4,870$.

3. Terdapat pengaruh yang signifikan kecerdasan interpersonal terhadap kemampuan menulis cerita pendek siswa SMP Negeri di Jakarta Selatan. Hal tersebut dibuktikan dengan nilai Sig. 0,013 $<0,05$ dan thitung = 2,578.

\section{DAFTAR PUSTAKA}

Chaer, A. (1994). Linguistik umum. Jakarta: Rineka Cipta. 
Diskursus: Jurnal Pendidikan Bahasa Indonesia

Vol. 1, No. 1, April 2018, pp. 97-108

p-ISSN: 2615-4935

e-ISSN: 2615-4943

Lwin, M., dkk. (2008). Cara mengembangkan berbagai komponen kecerdasan. Jakarta: Indeks.

Sumardjo, J. (2001). Beberapa petunjuk menulis cerpen. Bandung: Mitra Kencana.

Tarigan, H.G. (2001). Pengajaran gaya bahasa. Bandung: Angkasa.

Widyamartaya, A., \& Sudiati, V. (2005). Kiat menulis deskripsi dan narasi, lukisan dan cerita. Yogyakarta: Pusataka Widyatama. 